\title{
On the Equivalence of Tariffs and Quotas for Customs Unions
}

\author{
by \\ Jørgen Drud Hansen \\ and \\ Davide Sala
}

Discussion Papers on Business and Economics

No. 11/2013

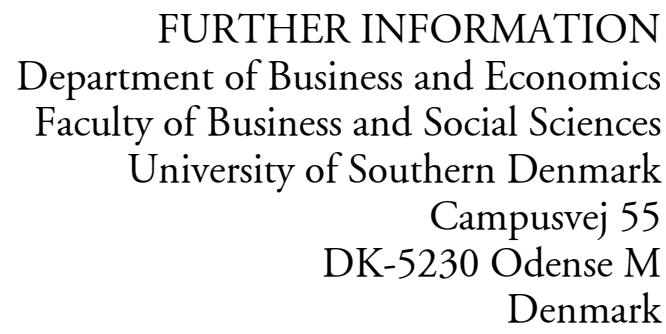

Tel.: +4565503271

Fax: +4565503237

E-mail: 1ho@sam.sdu.dk

http://www.sdu.dk/ivoe 


\title{
On the Equivalence of Tariffs and Quotas for Customs Unions
}

\author{
Jørgen Drud Hansen* and Davide Sala*
}

\begin{abstract}
While quotas can be expressed in tariff-equivalent terms and have identical economic effects under some conditions, they do not share the same welfare implications with tariffs in the presence of a piecemeal reform (second-best). In this paper we show that this non-welfare equivalence persists in perfect competition when countries undergo regional integration. A Pareto improving customs union is nevertheless viable in both protection regimes, but it requires different trade policy adjustments. When we extend the analysis beyond the competitive framework and consider shocks to the economy or imperfect markets, this general desirability of unions is unfortunately lost. But we show that, interestingly, the equivalence between tariff and quota regimes can still arise under particular circumstances, and only quotas provide countries with full insurance from price fluctuations.
\end{abstract}

JEL classification: $F 13$, F15

Keywords: Equivalence, tariffs and quotas, customs union

* Department of Business and Economics, University of Southern Denmark 


\section{Introduction}

During the last half century, preferential trade agreements (PTAs) have represented a major feature of international relations. According to the annual World Trade Report 2011 (WTO 2011), more than 300 active regional trade agreements exist today, and most of them were established during the last two decades. The recent proliferation of PTAs is often attributed to the unsatisfactory progress of multilateral trade liberalization to achieve free trade. Yet, because of the discriminatory nature of PTAs, it is debated whether this form of trade liberalization is a "stepping stone" or a "stumbling stone" to multilateral trade liberalization. ${ }^{1}$

To investigate this issue, the literature on PTAs has modeled trade restrictions mainly in the form of tariff measures, even in times in which other trade policy instruments such as quotas, local content schemes, and excise duties have gained popularity, and tariff measures were contextually reduced in several GATT/WTO rounds. Such an approach has found justification in the equivalence result first established in Bhagwati (1965) between the effects of a tariff and its volume-quota equivalent in a competitive setting.

The equivalence of tariffs and quotas in the Bhagwati analysis refers to the allocation of resources in the economy, but a large body of literature has already noted that these two trade policy instruments can have entirely different welfare effects. In this paper we argue that thinking in terms of tariff equivalence may be misleading when analyzing regional trade integration. ${ }^{2}$ In this paper we extend this literature and show that this equivalence does not need to extend to a "welfare equivalence" of the two types of trade instruments when

\footnotetext{
* Department of Business and Economics, University of Southern Denmark

${ }^{1}$ See for example Bhagwati (1993). The first wave of regionalism took place in the 1960s, but failed to spread because of the United States supported multilateral approach. But the United States changed positions, and starting with the 1980s - has favored regional trade agreements. See Fernandez and Portes (1998) for a broad and extensive review on the "traditional" and "non-traditional" gains of regionalism.

${ }^{2}$ See Corden and Falvey (1985) and Falvey (1988) for important contributions to this literature. However, these analyses pay no specific attention to PTAs.
} 
countries undergo trade integration. The implication is twofold. First, regional integration can be generally desirable with both types of instruments, but it requires different trade policy adjustments. Paradoxically, tariffs and tariff-equivalent quotas that lead to the same preintegration welfare do not necessarily lead to the same post-integration level of welfare. Second, integration under the current WTO disposition can be a "stepping stone" to multilateral trade liberalization under a quota regime, but not under a tariff regime. The timing of the surge of the last wave of regionalism can therefore be related to the transition along the 1980s from tariff to non-tariff trade barriers common to many developing and least developed countries.

Since Bhagwati's equivalence ceases to hold in a non-competitive or uncertain setting, we find it interesting and novel to further investigate this welfare comparison in a variety of scenarios that prescind from the competitive equilibrium or perfect foresight.

Both PTAs and trade protection instruments appear in a large number of variants. For conciseness we focus only on the establishment of a customs union (CU) in case of tariffs or quotas, but our results would easily extend to the case of free trade areas (FTAs).

To compare the two regimes we have to be specific about trade policy both before and after the formation of the $\mathrm{CU}$. We assume that before the $\mathrm{CU}$ is established, the tariff regime consists of Most Favored Nation (MFN) tariffs. Applying Bhagwati's equivalence result, we assume that the quota in place is the tariff-equivalent quota, i.e. the quota that restricts imports for each country to the same quantity as in the case of the MFN tariff. We shall name this quota the Bhagwati quota.

As shown in Viner (1950), trade diversion may hinder the formation of a welfare-enhancing CU. A Pareto-superior integration is nevertheless viable and only requires the preservation of 
the union's external volume of trade. ${ }^{3}$ This requirement, first derived by Kemp and Wan (1976), constitutes the so-called "efficient rule", and commands the new common external tariff (CET) to be set at a level below the pre-union levels of tariffs.

In contrast, the efficient rule with quota protection simply demands unchanged volume quotas vis-à-vis non-member countries: unchanged trade volumes with the rest of the world shield member countries from trade diversion effects. Therefore, the achievement of welfareincrementing integration requires different trade policy actions with different trade barriers: tariff cuts in a tariff regime and the preservation of the volume quota to the original contingent in a quota regime.

This result, namely that the quota is automatically conducive to welfare gains in trade agreements, is hardly reconcilable with the "tariffication" process that started in 1995 by the WTO. But although theoretically valid, the applicability of this result is limited by the restrictive assumptions needed, namely perfect competition and perfect foresight. Our extension of the analysis to an uncertain environment or to cases of imperfect competition reveals that welfare outcomes become dependent on the nature of shocks or the type of market analyzed. While a general desirability for a trade agreement can no longer be established for either instrument, we nevertheless show that the pass-through of external shocks to union countries is diametrically different under the two regimes. The peculiarity of quotas for fixing the external volume of trade keeps playing a central role for this difference, too.

Clearly, our paper continues in the tradition of Kemp and Van (1976) and Krishna and Panagariya (2002). The latter article extends the former by considering a weaker but more common form of integration, namely free trade areas instead of customs unions. Our article

\footnotetext{
${ }^{3}$ The same rule ensures Pareto superior free trade areas (FTAs). See Krishna and Panagariya, 2002.
} 
investigates the consequence of trade integration when protection is initially achieved by means of quotas, and accounts for the observation that the surge of regionalism occurred in the early 1990s, when countries had progressively shifted from tariff to non-tariff barriers.

In section 2 we introduce our simple model with perfect competition and no shocks, and we compare the conditions for the implementation of the efficient rule in the quota regime to the known Kemp and Wan tariff case. In section 3 we introduce shocks into the model. In particular, we show that price volatility will react differently to different types of shocks under the two regimes. In section 4 we look at imperfect competitive markets and demonstrate that the formation of the $\mathrm{CU}$ in the two alternative cases of trade policy regimes may have different effects on prices and output for market equilibrium. Beyond the competitive framework, it is impossible to make any conclusions on the general desirability for CUs based on the efficient rule alone. Section 5 concludes.

\section{The efficient rule - tariffs versus quotas}

The Kemp-Wan theorem proves that CUs among any number of countries are unambiguously welfare enhancing if the common external tariff (CET) is set to preserve the pre-union level of external trade (i.e. unaltered trade levels with non-members). The theorem is derived for perfect competitive markets and for countries where the only trade barriers are tariffs. It is important to note that the tariff in accordance with the efficient rule does not necessarily maximize the welfare of the CU. For a large CU, trade diversion is associated with terms of trade gains, and to seize these gains policymakers in the unions ought to opt for a higher tariff level than the one implied by the efficient rule. But this action is of course detrimental to the welfare of non-members. 
In practice, it may be difficult to set the tariffs which exactly preserve the union's external volume of trade because this rule requires full information about all market conditions, i.e. elasticities of supply and demand on all markets (internally and externally to the CU). In this section we show that the efficient rule is fulfilled if the trade barriers are quotas. Preserving the quotas towards non-member countries will automatically preserve import from those countries. To study regional trade integration, we consider three countries $(h, p, f)$ and two goods $(x, y)$, like in Bagwell and Staiger (1999). Two of the countries, $h$ and $p$, have the political option to be in a regional trade agreement.

Comparative advantages determine net trade flows: Without loss of generality the home country $h$ exports good $y$ to the partner country $p$ and the rest of the world $f$ and imports good $x$ from $p$ and $f$. As a simplifying assumption, countries $p$ and $f$ do not trade with each other; they are just competing suppliers of the same good in $h$ 's market.

To mimic a partial equilibrium setting, we add also the numeraire sector ( $\operatorname{good} z)$, and assume that preferences are quasi-linear in this good. The technology to produce the numeraire good is constant returns to scale with one unit of labor required to produce one unit of output. Goods $x$ and $y$ are produced under non-decreasing costs.

While the numeraire good is freely traded, the other imported goods are subject to either a tariff or a volume quota in the destination country. Specifically, country $h$ is imposing a tariff on the imported good $x$, and its rate may vary with the origin of the good. Only under an MFN tariff, the rate imposed on $p$ and $f$ is identical, but it differs when $h$ engages in regional integration with country $p$. Country $h$ could alternatively restrict trade by means of bilateral volume quotas vis-à-vis its trading partners. Finally, countries $p$ and $f$ are also protecting their respective import sector $y$ either with a tariff or a quota. 
While factor markets, the market for quota licenses, and the numeraire sector are assumed to be perfectly competitive, we will consider different forms of competition in the markets for goods $x$ and $y$. The partial equilibrium analysis conveniently permits comparison of our results across these different types of markets. For perfectly competitive goods markets the conclusions we derive also extend to a general equilibrium analysis. Given good z's simple technology and its free trade status, the wage level equals one in all model versions.

The only assumption we need for balanced trade is that the numeraire good is produced in all countries. To make the analysis of regional integration interesting, we also assume that countries must be producing at least the numeraire good and the exported good. ${ }^{4}$ To have trade diversion as a potential outcome of trade integration, we further assume that the rest of the world is the most efficient producer.

Figure 1 illustrates the effects of a CU with tariff and quota protection, respectively.

(INSERT FIGURE 1 ABOUT HERE)

Figure 1: The efficient rule - tariffs and quotas

The curves $X^{f}$ and $X^{p}$ in panels a and b illustrate, respectively, $p$ 's and $f$ 's export supply curve of good $x$ with free trade. Curve $M$ in panel c illustrates the import demand curve of the home country (i.e. domestic demand of $x$ net of its domestic supply). $h$ 's total export supply curve is the horizontal sum of $f$ 's and $p$ 's export supply curves. In the equilibrium with free trade the total export supply curve is $X$, and the trade volume is thus $X_{0}$.

\footnotetext{
${ }^{4}$ In general equilibrium (non-quasi-linear preference) the numeraire sector is unnecessary and countries have to be diversified (producing both goods $x$ and $y$ ).
} 
Let us first consider the case of tariff protection. Prior to the formation of the $\mathrm{CU}$, country $h$ charges the MFN tariff $t_{1}$ on imports from $p$ and $f$. In the tariff-ridden scenario, the export supply curve shifts to $X^{f}+t_{1}$ in the rest of the world, and to $X^{p}+t_{1}$ in the partner country, and therefore $h$ 's new total export supply curve becomes $X+t_{1}$. Of the $X_{1}$ units of good $x$ that $h$ imports in equilibrium, $X_{1}^{f}$ units of this good come from the rest of the world, and $X_{1}^{p}$ units come from the partner country.

We now assume that countries $h$ and $p$ form a CU and eliminate the tariffs internally between the two countries. If the CET is maintained at the pre-union level $t_{1}$, trade will be stimulated between the two member countries but partly at the expense of trade with the rest of the world. In accordance with the efficient rule, the common external tariff should be set to $t_{2}$ $\left(t_{2}<t_{1}\right)$ to ensure that the same import volumes from the rest of the world can be maintained, i.e. $X_{1}^{f}=X_{2}^{f}$. After the establishment of the CU the export curves from the rest of the world and the partner country are illustrated by $X^{f}+t_{2}$ and $X^{p}$, respectively, resulting in $h$ 's total export curve depicted by $X+t_{2}$. Clearly, the formation of the CU under KempWan's (1976) efficient rule eliminates trade diversion effects and leads to a welfareenhancing CU. Exports from the partner country increase from $X_{1}^{p}$ to $X_{2}^{p}$, which equals the increase of total exports from $X_{1}$ to $X_{2}$ (trade creation only).

In the same figure we analyze the case of trade integration with quota protection. Our goal is to identify conditions that lead to a welfare-enhancing customs union. As a starting point, we exploit Bhagwati's (1965) equivalence result to ensure that countries in the quota regime face the same pre-union conditions as in the tariff equilibrium. If $h$ sets two bilateral volume quotas that restrict imports of good $x$ to $X_{1}^{p}$ units from $p$ and to $X_{1}^{f}=Q^{f}$ units from $f$, respectively, the quota equilibrium replicates the tariff equilibrium, i.e. the quantities that $h$ is importing from its two trading partners are the same in the two regimes. Hence, the resulting 
wedge between the domestic and the international prices in the quota regime must be identical to the one arising with the imposition of tariff $t_{1} \cdot{ }^{5}$ In this sense, these quotas are the tariff-equivalent to $t_{1}$. We shall denote them as the "Bhagwati-type quota". The allocation of resources in the quota regime and in the tariff regime is therefore identical. In our figure, $h$ 's domestic price is again $P_{1}$, and its total imports are $X_{1}$. Since both quotas are binding, the positive quota rents must equal the MFN tariff $t_{1}$ per unit imported. Assuming that these quota rents are captured by the importing country, Bhagwati's (1965) equivalence result ensures that the government revenue is also identical in the two pre-integration equilibria.

The formation of a CU between countries $h$ and $p$ that fully liberalizes trade among the members of the union but maintains unaltered trade barriers vis-à-vis non-members implies that $h$ 's quota to country $f$ remains at the pre-union level $X_{1}^{f}=Q^{f}$. The export supply curve from $f, X^{f, Q}$, is vertical at the quota limit. After the formation of the CU, $h$ 's total export supply curve $X^{Q}$, i.e. the horizontal sum of the two export supply curves $X^{f, Q}$ and $X^{p}$, is steeper than the export supply curve in the tariff regime, $X+t_{2}$, because of the inelastic segment of $f$ 's export supply curve in case of quotas. Although the slopes of the two curves are different, the total export supply curve in the quota case and the total supply curve in the tariff case must cross each other at $P_{2}$. The post-integration equilibrium is at the intersection of the new total supply curve $X^{Q}$ and the import demand $M$. Because $f$ 's total exports to the union are the same as in the case of Kemp and Wan's efficient CET $t_{2}$, the final equilibrium must also be identical, and the $\mathrm{CU}$ in the quota case must be welfare-enhancing, too. This

\footnotetext{
${ }^{5}$ A bilateral quota is essential to the argument. A total volume quota of $X_{1}^{p}+Q^{f}$ set by country $h$ would also possibly entail trade diversion among the imports from the two source countries, like in the tariff case. However, the argument we are making would still carry on as long as country $h$ imports at least $Q^{f}$ from country $f$ in the post-integration equilibrium.
} 
result is not specific to our partial equilibrium setting, but it carries over to a general equilibrium approach. ${ }^{6}$

The above result reaffirms the general desirability for CUs and FTAs in the presence of quota protection and clearly hinges on the preservation of trade volumes in the post-union equilibrium to the pre-union levels. Therefore, it requires that the initial quota $Q^{f}$ remains binding after the union formation.

To see that this is always the case, notice that the two initial pre-union Bhagwati quotas (the quotas equivalent to the MFN tariff $t_{1}$ ) are both binding in the pre-union equilibrium. The establishment of a CU that removes the quota for imports from the partner country but not from the rest of the world lowers the market price. Yet the final domestic price exceeds the free trade equilibrium price as total imports are less than they would be under free trade. Therefore, the restriction on imports from the rest of the world $f$ must be effective. ${ }^{7}$

While the preservation of the external volumes of trade is central to Pareto superiority of trade integration in both trade regimes, the strategy to achieve the efficient rule differs in the two regimes. In the tariff case, an alteration of the pre-union protection levels and a selection of a new CET are required. In the quota case no actions at all are involved: The maintenance of the pre-integration quotas vis-à-vis non-members is all that is required.

The intuition for this result is in the different adjustment mechanism that the two trade protection instruments trigger. Since tariffs restrict trade through prices, they distort the price of each unit traded and confer a competitive advantage to producers in $p$ when trade policy is discriminatory. Producers in $f$ can nevertheless sell in country $h$ as long as they can match the price asked by producers in the $\mathrm{CU}, P_{2}$. By contracting exports, producers in $f$ can indeed

\footnotetext{
${ }^{6}$ It is easy to check that our framework can be rewritten in the general vector form as presented in Feenstra (2004), ch. 6, and verify that the sufficient condition for welfare-enhancing unions, p. 190, holds in our case, too. And clearly our results are also valid for formation of FTAs.

${ }^{7}$ Provided the $M$ curve crosses the $X^{Q}$ curve to the left of $X_{1}$, the initial quota $Q^{f}$ will always be binding.
} 
produce at a lower marginal cost and compensate for their artificial competitive disadvantage by accepting a lower price (terms of trade loss).

In the quota regime, imports are restricted through quantities. This distorts prices when quotas are exhausted. Indeed, in panel c the export supply in the quota-protected trade coincides with the free trade export supply up to $X_{1}$ units of good $x$. If $h$ were to import only this amount, $X_{1}^{f}$ units would be coming from $f$, exactly as in the free trade equilibrium. If $h$ wished to import more of this amount, the additional units could only come from the partner country because of the binding quota on imports from $f$ (i.e. no trade diversion, only trade creation). ${ }^{8}$

The WTO rule for the formation of CUs prescribes that the post-union protection should not result higher than pre-union levels. Whether this rule alone can promote welfare-enhancing regional trade agreements largely depends on the prevailing protection regime: It is not necessarily welfare conducive in the tariff regime, while this is the case in the quota regime.

This advantage of quotas put the "tariffication process" pursued by the WTO into a new perspective. Tariffication prior to CU formations makes the welfare effect of CUs ambiguous. However, tariffication can still be justified on theoretical grounds by the well-known objections to quotas inherent to the lack of transparency, the difficulties of quota-licensing, and rent-seeking.

\footnotetext{
${ }^{8}$ The reader may note that ultimately this result is mere an application of the case of CUs of the more general notion that "quota distortions do not spill over into other markets", as proven in Corden and Falvey (1985), which is at the core of the non-equivalence of tariffs and quotas for piecemeal reforms (see Falvey, 1988).
} 


\section{Demand and supply shocks}

The preceding section demonstrates a general desirability for CUs if the tariffs are set in accordance with the efficient rule or, alternatively, quotas are preserved at the level prior to the formation of the CU. However, this result is not robust if a country faces uncertainty and tariffs are set based on normal market conditions without accounting for unexpected shocks. While the welfare effects of CUs differ between the tariff regime and the quota regime, which protection regime entails higher welfare levels is contingent on the specific circumstances. The appeal of a simple rule for a general desirability for trade integration is unfortunately lost.

We show this result with reference to both internal and external shocks to the union: an export supply shock in the partner country, an import demand shock in the home economy, and an export supply shock in rest of the world.

Figure 2 illustrates the effect on the market equilibrium of an export supply shock in the partner country.

\section{(INSERT FIGURE 2 ABOUT HERE)}

Figure 2: Export supply shock in partner country

The Kemp-Wan tariff is $t$, and the equilibrium without shocks is illustrated by point $A$, where the total export supply curve in the tariff regime $(X+t)$ and the export supply curve in the quota regime $X^{Q}$ both cut the import demand curve $M$ in $A$. The market price without shocks is thus $P^{t}$. 
We first consider the case of a negative productivity shock in the partner country. ${ }^{9}$ The export supply curve in the partner country shifts upwards, and so does $h$ 's total export supply curves in the two regimes: $(X+t)$ and $X^{Q}$ in Figure 2 shift to $(\hat{X}+t)$ in the tariff regime and to $\hat{X}^{Q}$ in the quota regime, respectively. Notice that the total export supply decreases with the same quantity in both regimes at the initial equilibrium price $P^{t}$, and therefore $(\hat{X}+t)$ intersects $\hat{X}^{Q}$ at this price. The new equilibrium is point $B$ for the tariff regime and $C$ for the quota regime. Because the export supply in the quota regime is more rigid than the corresponding export supply in the tariff regime, the shock translates as illustrated into a greater price increase in the quota regime than in the tariff regime, i.e. $\hat{P}^{Q}>\hat{P}^{t}>P^{t}$. The quota regime therefore implies higher price volatility in case of internal supply shocks.

It also implies higher price volatility in the presence of shocks to the import demand: When the import demand curve shifts upwards or downwards in Figure 2, the swing in domestic prices in the quota regime is larger than in the tariff regime.

Finally, we look at the case of an external export supply shock. For shocks that originate in $f$, $h$ is insulated only if its supply curve is unchanged. Since the quota is binding, export supply shocks in the rest of the world have no effects on the total export supply curve in the quota regime. In contrast, in the tariff regime the total export supply curve will shift upwards in case of negative productivity shocks and downwards in case of positive ones. Therefore, the price volatility is higher in the tariff regime than in the quota regime.

In conclusion, the effects of shocks on price volatility can be diametrically opposite depending on the origin of the shocks. Shocks that originate internally to the CU translate into greater price volatility in quota regimes than in tariff regimes; conversely, external

\footnotetext{
${ }^{9}$ As the export supply reflects production minus domestic demand from the exporting country shocks may also be due to changes in demand in the exporting country.
} 
supply shocks only influence market domestic prices in the tariff regime, i.e. the quota regime ensures complete insulation.

Note that price volatility per se is not necessarily bad. As volatility has two sides, the country can experience more severe price increases but also more pronounced price decreases. While a price increase favors producers and penalizes consumers, and vice versa for a price decrease, we need more structured assumptions on for example the risk aversion of preferences before normative conclusions can be made. A welfare comparison of the two protection regimes is therefore not possible to carry out in the above simple setup.

However, if the objective of governments is to sterilize the country from external shocks, the two regimes require different trade policies. ${ }^{10}$ While in a quota regime no changes to the volume of the external quota are required, $h$ 's tariff rates in a tariff regime should be changed instantaneously to shocks to ensure that its export supply curve is maintained in its original position. Sterilization from external shocks in a tariff regime may thus require detailed information about the development of the conditions on markets, while no information is needed in the quota regime and, hence, this regime appears to be more suitable than tariff protection.

Developing countries often suffer from lack of deep financial markets and limited possibilities to hedge against external shocks. The insulating capacity of trade agreements may therefore have constituted an important motive for integration of developing countries in the early 1990s when governments had largely shifted to non-tariff barriers (Laird and Yeat, 1990). If the regional integration is partly driven by the insurance argument, as suggested in Fernandez and Portes (1998), the analysis above contributes to explain a greater appeal of

\footnotetext{
${ }^{10}$ See Newbery and Stiglitz (1981) for a discussion on this topic and on why governments would want to pursue such strategies.
} 
regional integration in times of quota protection (end of 1980s) than in times of tariff protection (the 1970s).

However, as stressed by Newbery and Stiglitz (1981) using trade policy as a remedy towards financial market failures is suboptimal. The preferable option is to address the market failures directly by developing the financial markets. Yet this result also opens the door to a different timing logic. The complete insulation that a quota regime buys is not peculiar to regional integration, but rather to the quota instrument itself. As tariff cuts have become more pervasive in subsequent GATT rounds, countries whose access to financial markets was restricted have found the transition towards a quota regime rewarding in the first place and have only subsequently found regional integration to be possibly desirable.

The extension of our comparative analysis on CU formation in the two trade policy regimes to the presence of uncertainty leaves no simple conclusion on the desirability for regional integration agreements in either regime. The only general conclusions for this part of the analysis are that the two regimes will generally lead to different welfare levels and that only a quota regime can ensure no pass-through in case of shocks external to the union.

\section{Imperfect competition}

Bhagwati (1965) notes that by limiting foreign producers' output, quotas, in contrast to tariffs, strengthen firms' market power on the protected domestic market. Under such circumstances the size of Kemp-Wan's optimal tariff and Bhagwati quotas become sensitive to the strategic behavior of the firms. We present a simple model based on a homogenous oligopoly with Cournot or Stackelberg competition to show that the effects of tariffs and quotas can also be identical in imperfect markets. 
The domestic market in country $h$ is assumed to be provided by a producer in a partner country $p$ and a producer in the rest of the world $f$, i.e. we disregard domestic production in the home market. The inverse demand function in the domestic market in country $h$ is specified by:

$$
P=a-b X
$$

where - using the same notation as in the previous sections - total output is given by:

$$
X=X^{p}+X^{f}
$$

In each of the two countries, $p$ and $f$, output is produced at the same unit costs $c$, and trade costs other than tariffs are neglected. To determine market equilibrium, the strategic game between the two producers is either a Cournot game or a Stackelberg game with one of the producers as leader and the other as follower.

The analysis proceeds as follows. The benchmark is the tariff regime. First, market equilibriums are derived for the tariff regime before and after formation of a CU based on the efficient rule of an import preserving tariff imposed on the exporter from the rest of the world, $f$. We look at three games: The Cournot game, a Stackelberg game that has the producer in the partner country $p$ as leader, and a Stackelberg game which has the producer in the $f$ as leader. Next, similar analyses are conducted for a quota regime where each country before the formation of the $\mathrm{CU}$ is allowed to export the quantity exported in the tariff regime. Formation of the CU removes the quota from the partner country, while it is maintained towards the producer in the rest of the world. 


\section{a. The Cournot game}

Before formation of the CU, an MFN tariff $t$ has been imposed to the producer in each of the two countries $p$ and $f$. In the Cournot game each producer optimizes his profit with respect to output assuming that the competitor's output is given. This gives the "best response" or reaction functions for the two producers:

$$
\begin{aligned}
& X^{p}=-1 / 2 X^{f}+(a-c-t) / 2 b \\
& X^{f}=-1 / 2 X^{p}+(a-c-t) / 2 b
\end{aligned}
$$

To distinguish the pre-integration from the post-integration equilibrium, we adopt the convention to use subscripts 1 and 2, respectively. The pre-integration equilibrium outputs and price are therefore:

$$
\begin{aligned}
& X_{1}^{p}=X_{1}^{f}=\left(a-c-t_{1}\right) / 3 b \\
& P_{1}=\left(a+2 c+2 t_{1}\right) / 3
\end{aligned}
$$

Formation of the CU eliminates the tariff for trade between country $h$ and $p$, while imports from country $f$ are charged a tariff at $t_{2}$. Solving once more for the Cournot equilibrium, imports from $f$ are given by: $X_{2}^{f}=\left(a-c-2 t_{2}\right) / 3 b . X_{1}^{f}=X_{2}^{f}$ determines the importpreserving tariff rate from $f$ :

$$
t_{2}=t_{1} / 2
$$

In other words, the efficient rule demands tariffs to be reduced to half of its initial level. ${ }^{11}$ Using this result gives the Cournot equilibrium after formation of the CU:

\footnotetext{
${ }^{11}$ This result also appears in case of different unit costs before tariffs.
} 


$$
\begin{aligned}
& X_{2}^{p}=\left(a-c+t_{1} / 2\right) / 3 b \\
& X_{2}^{f}=\left(a-c-t_{1}\right) / 3 b \\
& P_{2}=\left(a+2 c+t_{1} / 2\right) / 3
\end{aligned}
$$

\section{( INSERT FIGURE 3 ABOUT HERE)}

\section{Figure 3: Cournot game in a CU with tariffs}

Graphically the Cournot solutions before and after the formation of the CU are illustrated in Figure 3 by the intersection points $C_{1}$ and $C_{2}$ between the reaction curves for the two producers $R_{t}^{i}\left(i=p, f\right.$ and $t=t_{1}$ or 0 or $t_{2}$, respectively).

We now turn to the quota regime. Before the formation of the $\mathrm{CU}$, exports from each of the two countries $p$ and $f$ are constrained to the volume of exports in the tariff regime. This restriction truncates the duty free reaction curves as the countries $p$ and $f$ are only allowed to export $X_{1}^{p}$ and $Q=X_{1}^{f}$, respectively. ${ }^{12}$ It follows that even in the case where one of the two producers from $p$ or $f$ exports less that the quota the other producer optimizes profits by exporting to the quota i.e. a stable Cournot equilibrium exists identical to the tariff equilibrium $\left(\mathrm{C}_{1}\right)$.

Formation of a CU that leaves the quota vis-à-vis country $f$ unaltered at $Q=X_{1}^{f}=X_{2}^{f}$ generates exactly the same market equilibrium as in the tariff regime $\left(\mathrm{C}_{2}\right)$. The import quota

\footnotetext{
${ }^{12}$ Here we assume that the exporters get the scarcity rent of the quota.
} 
truncates only the reaction curve from the rest of the world as illustrated in Figure 3 by the kinked bold curve consisting of the non-binding part of the reaction curve for duty free import from $f$ and the horizontal segment where the import quota is binding. The tariff and quotas are thus equivalent in this specific case.

\section{b. The Stackelberg game - producer in $p$ as leader}

We now assume that the producer in the partner country acts as Stackelberg leader in the strategic game in a tariff regime before the formation of the CU, i.e. the partner country optimizes his profit taking into account the reaction function $(3 b)$ of the competitor in the rest of the world. This gives the following solution prior to the formation of the CU:

$$
\begin{aligned}
& \hat{X}_{1}^{p}=\left(a-c-t_{1}\right) / 2 b \\
& \hat{X}_{1}^{f}=\left(a-c-t_{1}\right) / 4 b \\
& \hat{P}_{1}=\left(a+3 c+3 t_{1}\right) / 4
\end{aligned}
$$

After the formation of the CU only $f$ is charged a tariff $t_{2}$, and in that case imports from $f$ in the Stackelberg equilibrium make up $\hat{X}_{2}^{f}=\left(a-c-3 t_{2}\right) / 4 b$. The import-preserving tariff in this case follows from solving the condition $Q=\hat{X}_{1}^{f}=\hat{X}_{2}^{f}$ with respect to $t_{2}$. This gives:

$$
t_{2}=t_{1} / 3
$$

In other words, the level of tariffs towards the rest of the world should be reduced by about two-thirds compared with the more modest tariff reduction of about half in the Cournot case. Using (7) and that no duty is imposed on exports from the producer in $p$ gives the Stackelberg equilibrium:

$$
\widehat{X}_{2}^{p}=\left(a-c+t_{1} / 3\right) / 2 b
$$




$$
\begin{aligned}
& \hat{X}_{2}^{f}=\left(a-c-t_{1}\right) / 4 b \\
& \hat{P}_{2}=\left(a+3 c+t_{1} / 3\right) / 4
\end{aligned}
$$

Comparing (8a) with (5a) shows that the leader position of the producer in the partner country results in larger exports for this producer compared with the Cournot game.

\section{(INSERT FIGURE 4 ABOUT HERE)}

Figure 4: Stackelberg game in a CU with tariffs - producer in partner country as leader

Figure 4 illustrates the Stackelberg equilibrium in a tariff regime before and after the formation of a CU. The full drawn curve $R_{t=t_{1}}^{f}$ illustrates the reaction curve of the producer from the rest of world before the formation of the CU. The partner country optimizes subject to this reaction curve of the follower in the rest of world by choosing the export combination $S_{1}$, where the partner country exports $X_{1}^{p}$ and the rest of the world $X_{1}^{f}$. Due to the leader's behavior the partner country exports more than in the Cournot case. This also appears from Figure 4, where the alternative Cournot equilibrium from Figure 3 is illustrated by the point $C_{1}$ together with the reaction curve of the partner country $R_{t=t_{1}}^{p}$ relevant only in the alternative Cournot game. After the formation of the CU the CET is adjusted to $t_{2}=t_{1} / 3$ shifting the reaction curve of the rest of the world to $R_{t=t_{2}}^{f}$ and the Stackelberg equilibrium to $S_{2}$. The Stackelberg leader mistakenly perceives that the tariff is independent of the leader's output decision. In $S_{2}$ the CET has been manipulated to the level where the Stackelberg leader's output induces the follower in $f$ to maintain unchanged export to $h$. 
In the quota regime the quota eliminates the leader position of the producer in $p$. If exports from $f$ are bounded not to exceed $Q=X_{1}^{f}$, the best response from $p$ will be to optimize profit with the Cournot assumption of the given sale from $f$ at $Q$. The optimum will be at $p$ 's reaction curve $R_{t=0}^{p}$ for $X^{f}=Q$. The quota equilibrium is illustrated in Figure 4 by $C_{2}^{Q}$, where the truncated reaction curve from $f$ intersects $p$ 's reaction curve $R_{t=0}^{p}$. In case of a quota, the partner country $p$ will thus exploit the "tied hands" of the rest of the world by restricting its sale. A quota regime may therefore provide different market equilibrium compared with a tariff regime. Focusing welfare there are opposing interest between home and partner country depending on the two regimes. The partner country prefers the quota regime as the producer in the partner country has more market power and, hence, more profits in the quota regime compared with the tariff regime. The home country may prefer the tariff regime for the quota regime as it provides a lower price.

\section{c. The Stackelberg game - producer in f as leader}

Finally, we look at the case where the producer in the rest of world in the tariff regime is the leader and the partner country the follower. Before the formation of the CU the Stackelberg equilibrium is given by:

$$
\begin{aligned}
& \tilde{X}_{1}^{p}=\left(a-c-t_{1}\right) / 4 b \\
& \tilde{X}_{1}^{f}=\left(a-c-t_{1}\right) / 2 b \\
& \tilde{P}_{1}=\left(a+3 c+3 t_{1}\right) / 4
\end{aligned}
$$

Due to the role as leader exports from $f$ to $h$ are twice exports from $p$. 
After the formation of the CU, where tariffs are abolished towards $p$ but maintained at the reduced rate $t_{2}$ towards $f$, $h$ 's imports from $f$ make up $\tilde{X}_{2}^{f}=\left(a-c-2 t_{2}\right) / 2 b$. The import preserving tariff in this case follows from solving the condition $Q=\tilde{X}_{1}^{f}=\tilde{X}_{2}^{f}$ with respect to $t_{2}$. This gives the same result as in the Cournot case, namely that the tariffs should be halved, i.e. $t_{2}=t_{1} / 2$. The equilibrium is therefore:

$$
\begin{aligned}
& \tilde{X}_{1}^{p}=\left(a-c+t_{1}\right) / 4 b \\
& \tilde{X}_{1}^{f}=\left(a-c-t_{1}\right) / 2 b \\
& \tilde{P}_{1}=\left(a+3 c+t_{1}\right) / 4
\end{aligned}
$$

Equations (9a) to (9c) also describe the pre-integration equilibrium in the quota regime, as both the producer in $p$ and $f$ export to the quota limit. After the formation of the $\mathrm{CU}$, the quota vis-à-vis the producer in $f$ is unaltered and specified in (9b). The producer has incentives to make full use of it, i.e. the quota will be binding. To see this point, notice that the leader in the Stackelberg equilibrium with free trade would be exporting $(a-c) / 2 b$ (see (6a) with $\left.t_{1}=0\right)$, which exceeds the maximum allowed by the quota (9b). As the producer is exporting the same amount as in the alternative tariff regime, the post-integration equilibrium in the quota regime replicates the tariff equilibrium, i.e. the two regimes are equivalent.

\section{d. Domestic production in $h$}

We have assumed so far that the market in $h$ is only serviced by the two exporters from $p$ and $f$, i.e. domestic production is neglected. This assumption is crucial for the results above. If there is also a producer in market $h$, the market structure changes to triopoly. Similarly to the 
duopoly case above, a Cournot equilibrium for the pre-integration and post-integration scenarios may be derived in the tariff regime. This time, however, the equilibria in the alternative quota regime will differ substantially. Before the formation of the CU, $h$ 's imports are restricted to the quotas for each of the two exporters, and therefore the domestic producers can act as a monopolist facing the net demand curve, i.e. total demand less the restricted total imports. Given the monopolist's greater market power, the producer will charge a higher price and produce a lower output than in the tariff regime. This point is quite similar to the seminal result by Bhagwati (1965) for a two-country analysis.

After the union formation, the market power of the producer in $h$ is weakened by the elimination of the quota against the partner country, and the exporter in $p$ now competes actively in a duopoly with the producer in $h$ for the net demand given by total demand less imports from $f$. As the market power in the duopoly of the quota regime nevertheless exceeds the market power in the triopoly of the tariff regime, the two regimes are clearly nonequivalent in the post-integration equilibrium, too.

\section{Concluding remarks}

Beyond tariffs a large number of other protectionist instruments are used to influence trade flows on the global markets. This paper presents a comparative analysis of the effects of regional trade integration with different trade policy regimes. In particular, we compare customs union formation with tariffs versus quota protection. Although this comparison may appear highly stylized, it shows effectively that Bhagwati’s (1965) equivalence and nonequivalence results on the economic effects of tariffs and quotas do not readily or necessarily extend to the case of regional integration. 
Because regional integration entails multilateral (as opposed to unilateral) liberalization of a discriminatory (as opposed to non-discriminatory) nature, Bhagwati's equivalence result between quota and tariff in competitive markets does not readily extend to regional integration, in the sense that tariffs and quotas needed to achieve a Pareto superior integration are not the equivalent of one another in the post-integration equilibrium. Welfare-enhancing CUs require different trade policy adjustments in the tariff and in the quota regimes. While the common external tariff must be adjusted to ensure the preservation of trade volumes with non-member countries, quotas should be kept unaltered at the pre-integration level.

Therefore, if the pre-integration tariffs and quotas are equivalent to one another, they cannot be equivalent in the Bhagwati sense in the post-integration equilibrium, too.

Furthermore, tariffs and quotas are generally non-equivalent in imperfect markets, yet in some (not so special) circumstances, e.g. the Cournot equilibrium and the Stackelberg equilibrium with a foreign leader, equivalence between tariffs and quotas can arise. This equivalence, however, is fragile as it is quite specific to the assumptions. For instance, just adding a player in the oligopoly à la Cournot changes this conclusion.

The comparison of the effects of regional integration is based on the assumption of KempWan's (1976) efficient criteria. Calculating and implementing the tariff rate that ensures the preservation of trade volumes with third-party countries is far from easy as it requires that the policy maker has full information on market conditions. This complexity would increase further in an FTA where each member country has to adjust its tariff rate (Krishna and Panagariya, 2002). A quota regime automatically ensures that exports from third-party countries are unchanged after formation of the CU. Administratively it is therefore easier to 
implement the efficient rule in a quota regime. However, we do not see this prediction necessarily as contradicting the process of tariffication initiated by the WTO in recent decades, i.e. the conversion of all non-tariff barriers to tariffs equivalent and their gradual reduction. First, our model assumes away all administrative costs related to quota implementations, which, in practice, could be substantial. More importantly, in comparing advantages and disadvantages of various trade policy instruments, practical problems in establishing the efficient rule are probably of less importance compared with other aspects such as transparency of trade policy. Therefore, such a process may nevertheless be justified with the aim of creating a fruitful framework for future negotiations on trade liberalization.

The analysis above only points to some examples where non-equivalence may occur, but other topics are worth to be considering in a comparative perspective across protection regimes. In particular, quality heterogeneity and upgrading in conjunction with CUs. Due to the constraint of the trade volume in a quota regime, the exporting country outside the $\mathrm{CU}$ may have an incentive to specialize in high-quality products compared with the producers in the CU. 


\section{Literature}

Acharya, R., Crawford, J.A., Maliszewska, M., and Renard, C. (2011). “Landscape”, in Chauffour, J.P., J.C. Maur (eds.) Preferential Trade Agreements Policies for Development: A Handbook, Washington DC: The World Bank.

Bagwell, K. and Staiger, R. (1999). An economic theory of GATT, American Economic review, 89, pages 215-248.

Bhagwati, J. N. (1965). On the Equivalence of Tariffs and Quotas. In: Robert E. Baldwin et. al. (eds), Trade Growth and the Balance of Payments: Essays in Honor of Gottfried Haberler. Chicago: Rand-McNally, pages 53-67.

Bhagwati, J. N. (1993). Regionalism and Multilateralism: An Overwiev. In: De Melo, Jaime, and Arvind Panagariya (eds.), New Dimensions in Regional Integration, Cambridge University Press.

Corden, W. M. and Falvey, R. E. (1985). Quotas and the second best, Economics Letters, 18(1), pages 67-70.

Falvey, R. E. (1988). Tariffs, quotas and piecemeal policy reform, Journal of International Economics, 25(1-2), pages 177-183.

Feenstra, R. C. (2004). Advanced International Trade: Theory and Evidence. Princeton University Press.

Fernandez, R., and Portes, J. (1998). Returns to Regionalism: An Evaluation of NonTraditional Gains from RTAs. World Bank Economic Review. 
Kemp, M. and Wan, H., Jr. (1976). An Elementary Proposition Concerning the Formation of Customs Unions. In: Three Topics in the Theory of International Trade: Distribution, Welfare and Uncertainty. Amsterdam: North Holland.

Krishna, P. and Panagariya, A. (2002). On Welfare-Enhancing Free Trade Areas. Journal of International Economics, 57, pages 353-367.

Laird, S. and Yeat, A. (1990). Trends in Nontariff Barriers of Developed Countries. 19661986. Weltwirtschaftliches Archiv, 126, pages 299-325.

Newbery, D., M., Stiglitz, J. E. (1981). The Theory of Commodity Price Stabilization. Clarendon Press, Oxford.

Viner, J. (1950). The Customs Union Issue. New York: Carnegie Endowment for International Peace.

World Trade Report (2011). The WTO and preferential trade agreements: From co-existence to coherence, World Trade Organization. 
Appendix 1: Figures

Figure 1: The efficient rule - tariffs and quotas.

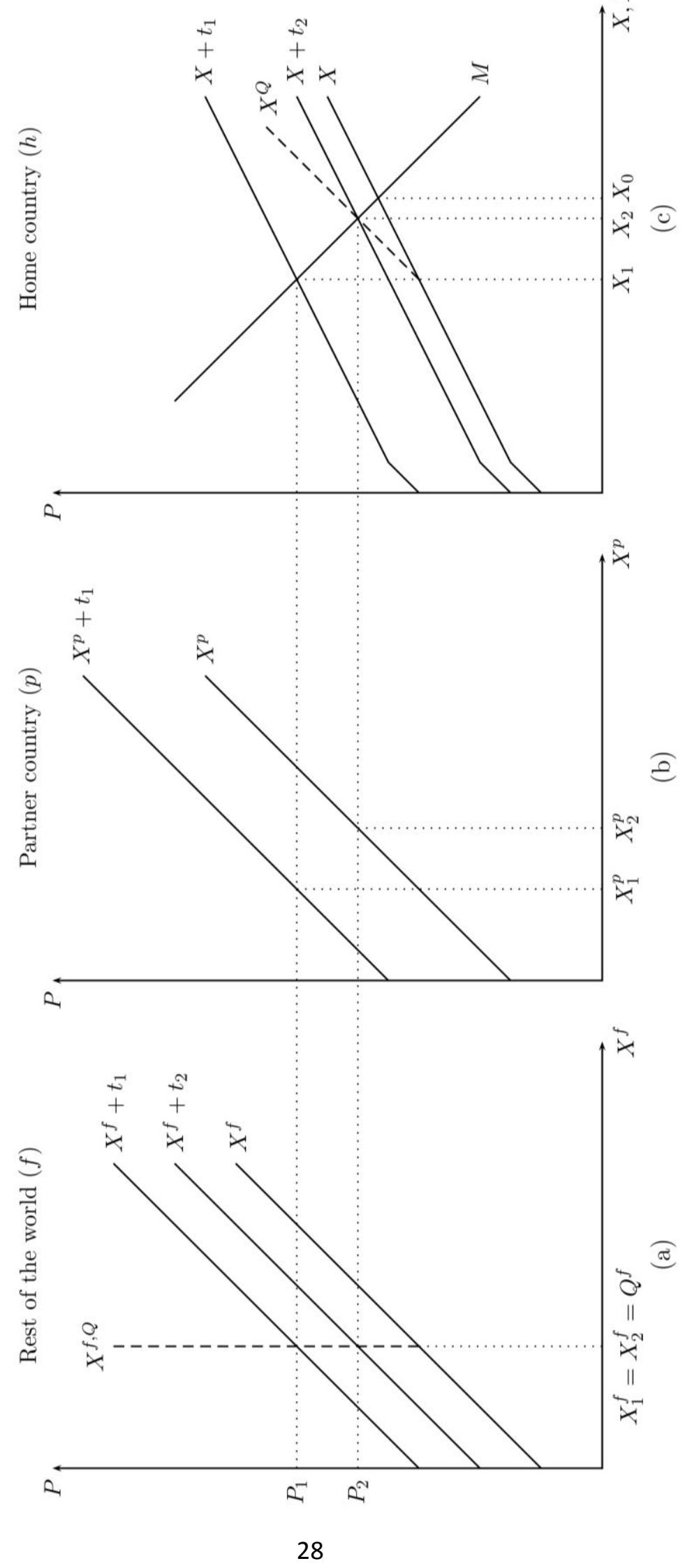


Figure 2: Export supply shock in partner country.

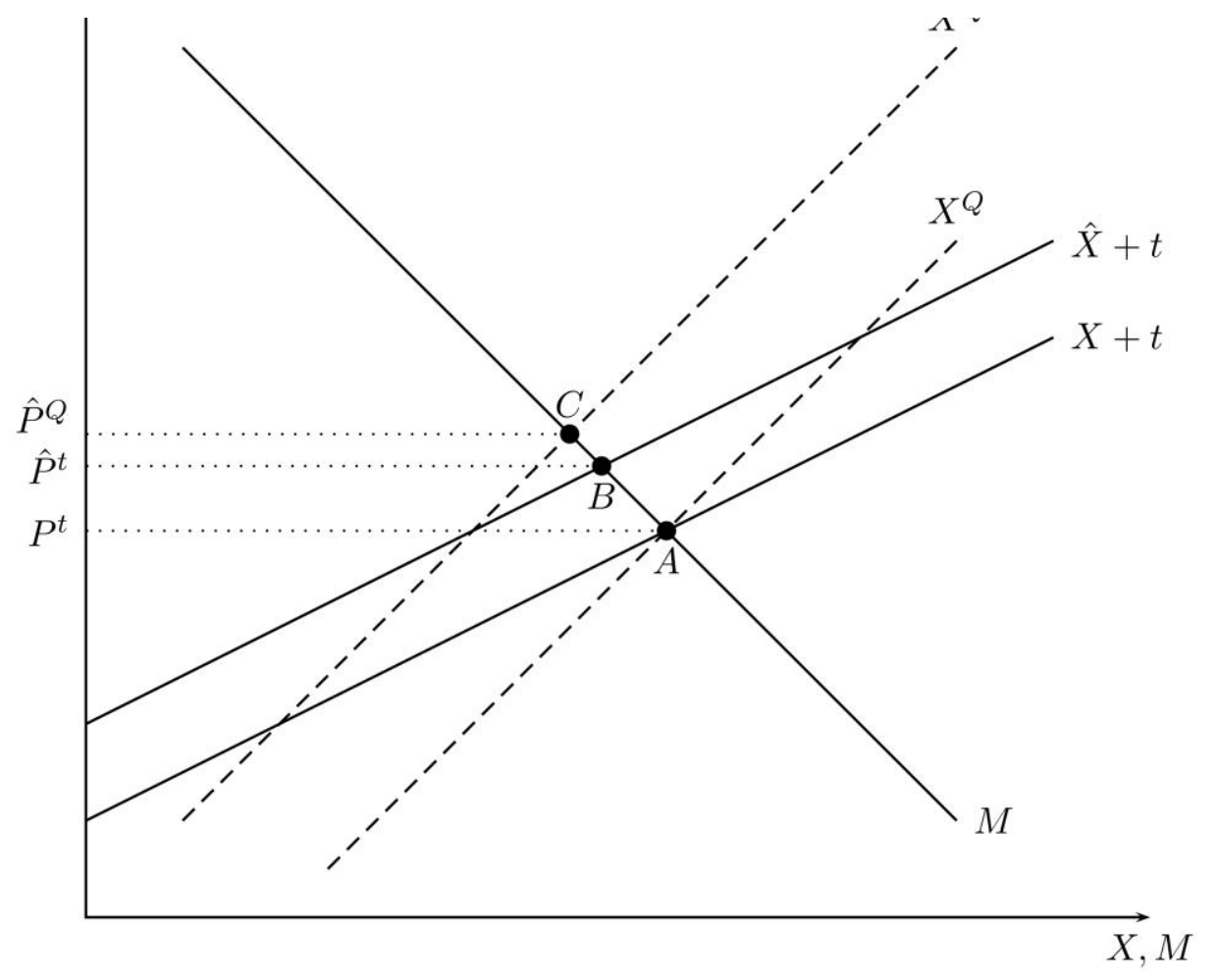


Figure 3: Cournot competition in a CU - tariffs or quotas.

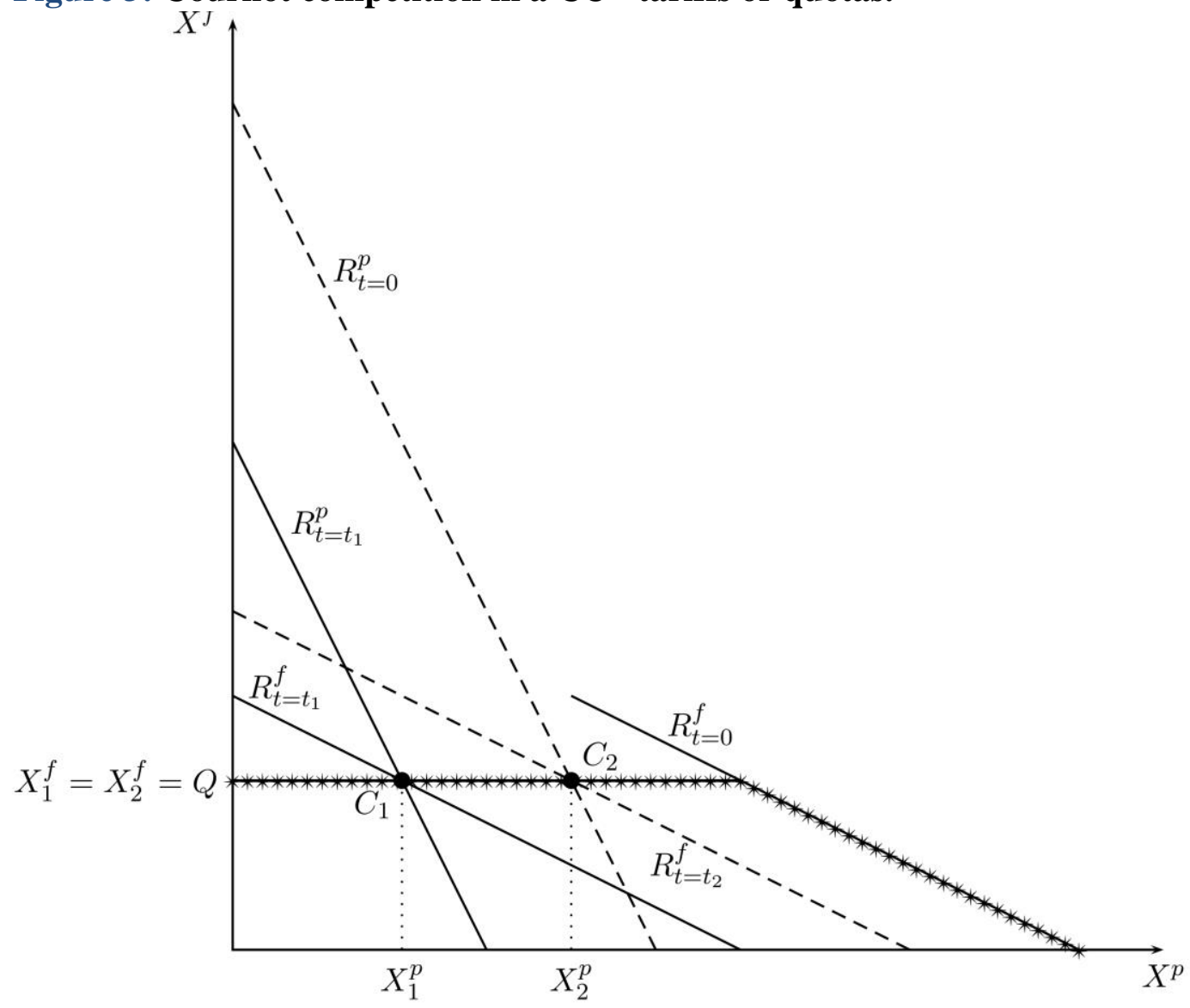


Figure 4: Stackelberg competition in a CU - tariffs or quotas.

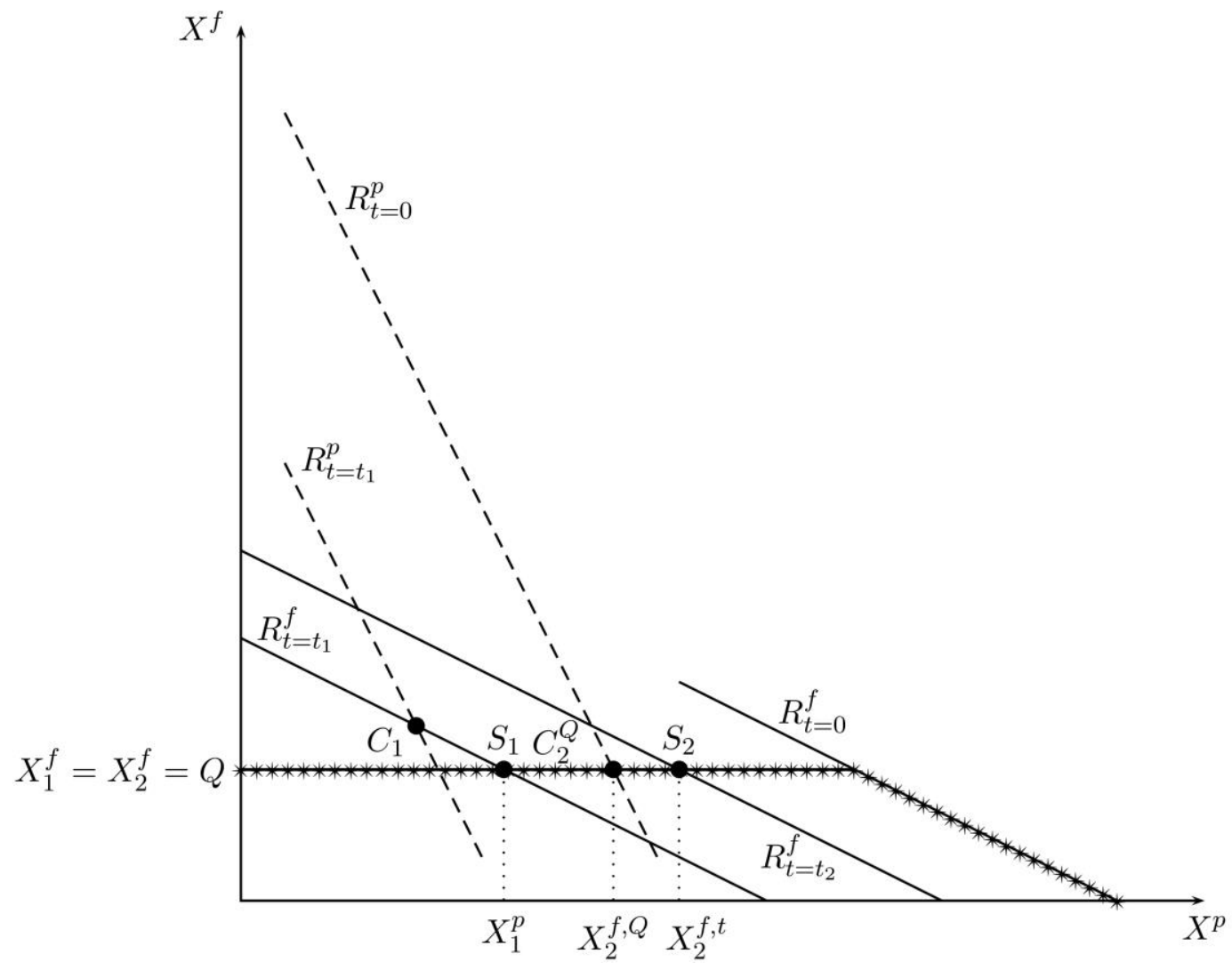

